Witold WaRCHOLIK

Akademia Pedagogiczna, Kraków

\title{
Europejskie programy GNSS na rynku globalnych systemów nawigacyjnych
}

Program Galileo jest największym projektem przemysłowym realizowanym w ramach zintegrowanych struktur europejskich (Galileo..., 2007). Inicjatywa w zakresie cywilnej nawigacji satelitarnej GNSS (Global Navigation Satellite System), realizowana od lat 90. XX w., ma zapewnić krajom UE niezależność w jednym z kluczowych sektorów gospodarki. Projekt ma jednocześnie wymiar ponadregionalny, wynikający z planowanej konstelacji satelitów, obejmującej sygnałami w sposób optymalny potencjalnych użytkowników w każdym punkcie globu.

Coraz szersze spektrum działalności gospodarczej, bazującej na precyzyjnej informacji dotyczącej lokalizacji i czasu, predysponuje gwałtowny rozwój przedsiębiorstw związanych z systemami nawigacji satelitarnej. Tego typu systemy nabierają charakteru zasadniczych infrastruktur w społeczeństwach wykorzystujących je w logistyce transportu, nadzorze nad sieciami energetycznymi i operacjach finansowych $\mathrm{i}$ in.

Celem niniejszego opracowania jest przedstawienie uwarunkowań rozwoju i charakterystyki wybranych aspektów realizacji europejskiego programu nawigacji satelitarnej Galileo, z wyszczególnieniem wpływu na jego przebieg procesów integracji europejskiej i intensyfikacji powiązań międzynarodowych. Bliższą uwagę w opracowaniu zwrócono na ocenę współpracy podmiotów gospodarczych w ramach projektu Galileo, który będąc strukturą o charakterze publicznym i przynależąc do instytucji europejskich, w założeniach miał stanowić pierwsze europejskie partnerstwo publiczno-prywatne. Przybliżono również konsekwencje opóźnień i ewentualnego wstrzymania realizacji projektu Galileo. Zagadnieniem ujętym skrótowo w pierwszej części opracowania jest rozmieszczenie systemów nawigacyjnych na świecie oraz zarys funkcjonowania przedsiębiorstw i rynku produktów związanych z nawigacją satelitarna, z oceną zapotrzebowania na tego typu usługi. W artykule, obok publikowanych danych statystycznych, wyników badań marketingowych i analiz rynku, m.in. Eurobarometru, opracowań Canalys i ABI Research, wykorzystano materiały zawarte w komunikatach Komisji do Parlamentu Europejskiego i Rady oraz rozporządzeniach Parlamentu Europejskiego i Rady z lat 2006-2007, a także raporcie General public survey on the European Galileo Programme z 2007 r.

GNSS tworzą zarówno systemy nawigacji satelitarnej (satellite based navigation systems), do których zaliczają się GPS i GLONASS, jak i trzy podstawowe typy systemów wspomagających (augmentation systems): naziemne (GBAS - Ground Based Augmentation Systems), satelitarne (SBAS - Satellite Based Augmentation Systems) oraz umieszczane na 
statkach powietrznych (ABAS - Aircraft Based Augmentation Systems). Według stanu na 2007 r., stopniowej modernizacji podlega działający niezawodnie amerykański system GPS, kompatybilny z innymi GNSS, odporny na zakłócenia, oparty na satelitach z bloków II/IIA, II-R oraz 2R-M (wprowadzanych od 2005 r., transmitujących kod cywilny już na 2 pasmach częstotliwości; od 2008 r. satelity z trzecim pasmem). Nie w pełni funkcjonalny jest rosyjski system GLONASS, jednakże według zapewnień Ministerstwa Obrony Rosji, całkowita operacyjność, opartą na konstelacji 24 satelitów, osiąnie już w 2010 r. Spośród satelitarnych systemów wspomagania, najefektywniejszych z punktu widzenia dokładności (accuracy), pokrycia (coverage), dostępności (availability), niezawodności (reliability) i wiarygodności (integrity), w zaawansowanym stadium wdrożeniowym znajdują się amerykański WAAS i japoński MSAS. Europejski SBAS o nazwie EGNOS powstał wysiłkiem przemysłu i instytucji badawczych przy budżecie w sektorze publicznym rzędu 2,5 mld euro w latach 1996-2006 (Communication... 2007), a pełną funkcjonalność powinien osiagnąć w 2009 r. (Kramarz, Warcholik 2005). Wśród państw budujących lub deklarujących plany budowy satelitarnych systemów wspomagających znajdują się: Kanada (CWAAS), Japonia (QZSS), Indie (GAGAN), Chiny (SNAS), Australia i Brazylia.

\section{RYNEK PRODUKTÓW I ZAPOTRZEBOWANIE}

\section{NA USŁUGI ZWIĄZANE Z RADIONAWIGACJĄ SATELITARNĄ}

Z raportu Komisji do Parlamentu Europejskiego i Rady (Taking stock... 2006) wynika, że już w 2005 r. obroty na światowym rynku produktów i usług związanych z radionawigacją satelitarną osiagnęły 60 mld euro, a roczny wskaźnik wzrostu w ciągu ostatnich pięciu lat wyniósł $25 \%$.

Listę produktów związanych z GNSS otwierają odbiorniki do nawigacji satelitarnej, w tym ręczne nawigatory, urządzenia, w których moduł GPS pełni funkcję drugorzędną (telefon komórkowy, PDA), i przenośne PND. Obok zewnętrznych modułów GNSS, map cyfrowych, nawigacyjnych serwisów internetowych i systemów telematycznych, odbiorniki stanowią produkty głównie przedsiębiorstw, takich jak: TomTom, Garmin, Magellan, Navteq, Tele Atlas, Navman i Mio Technology. Firmy, które charakteryzują się największymi obrotami na rynkach EMEA (tab. 1), notują stałe przyrosty sprzedaży, przykładowo w latach 2005-2006 rzędu 300\% (Garmin) i 200\% (TomTom), a gwałtowny wzrost ich przychodów i zysków przypomina analogiczną sytuację z najefektywniejszych lat na rynku komputerowym. Rośnie konkurencja przedsiębiorstw, także w wymiarze globalnym - przykładem może być europejski TomTom, który po sześciu latach swojej działalności i 80\% wzroście przychodów w 2006 r., dogania na rynku produktów radionawigacji satelitarnej amerykańskiego lidera, jakim jest Garmin.

Tab. 1. Wybrane charakterystyki przedsiębiorstw - liderów rynku nawigacyjnego

\begin{tabular}{|l|c|c|c|c|c|c|c|}
\hline \multirow{2}{*}{ Firma } & \multicolumn{2}{|c|}{ Zysk netto [mln euro] } & \multicolumn{2}{c|}{ Przychody [mld euro] } & \multicolumn{3}{c|}{ Produkcja na rynek [\%] } \\
\cline { 2 - 8 } & 2005 & 2006 & 2005 & 2006 & Ameryka Pn. & Europa & Azja \\
\hline Garmin & 236,3 & 390,3 & 780,3 & 1346,8 & 62 & 33 & 5 \\
\hline TomTom & 143,0 & 222,0 & 720,0 & 1364,0 & 8 & 90 & 2 \\
\hline
\end{tabular}

Źródło: na podstawie „Nawi”, nr 5 (15), 2006, s. 3 
Postęp technologiczny, wzrost popytu i mechanizmy konkurencji wśród producentów odbiorników GNSS wpłynęły bezpośrednio na spadek cen urządzeń nawigacyjnych, np. ręcznych nawigatorów GPS (ryc. 1). Badania rynku produktów związanych z radionawigacją satelitarną wskazują, iż w perspektywie najbliższych 20 lat będą dominować odbiorniki osobiste GNSS (głównie telefony komórkowe z nawigacją i kieszonkowe nawigatory), ocenia się (ryc. 2), że do 2025 r. firmy wyprodukują do 1.9 mld sztuk tych urządzeń. Będą one stanowić razem z produktami montowanymi w samochodach osobowych i dostawczych aż 98\% urządzeń na rynku, a łączną szacowaną liczbę 3,5 mld sztuk uzupełnią odbiorniki GNSS dla potrzeb transportu kolejowego, lotniczego i morskiego. Badania prowadzone przez ABI Research wykazały, że najwięcej użytkowników tego rodzaju sprzętu przybywa w Europie, a wkrótce ta tendencja pojawi się w Chinach i Indiach, gdzie w 2012 r. będzie się sprzedawać najwięcej systemów nawigacyjnych.

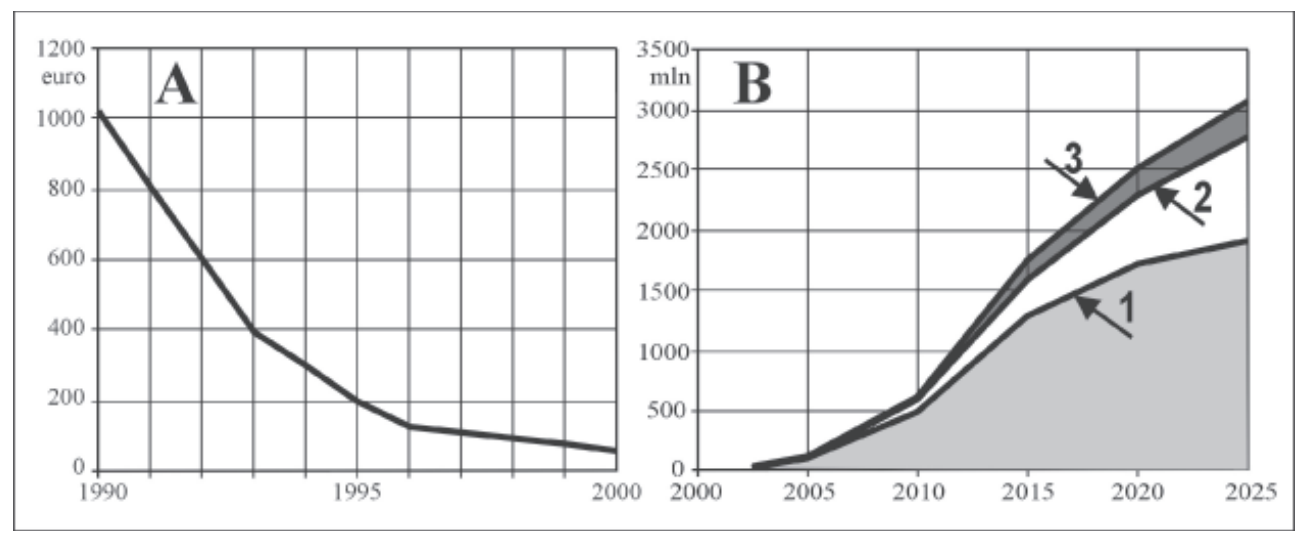

Ryc. 1. Wybrane charakterystyki rynku produktów GNSS

A - uśredniona światowa cena odbiornika GPS, B - perspektywiczna struktura produkcji odbiorników

GNSS: liczba wyprodukowanych odbiorników: 1 - osobistych,

2 - do samochodów dostawczych, 3 - do samochodów osobowych

Źródło: na podstawie Busines... 2005; The curent... 2006

Pobieżna ocena rynku produktów i usług w zakresie nawigacji satelitarnej zawężana jest zwykle do analizy branż związanych z geodezją, turystyką, transportem i łącznością. Zakres wykorzystania technologii nawigacji satelitarnej, zarówno GPS, jak i szerzej w ramach GNSS-1 czy też planowanego GNSS-2, jest jednak zdecydowanie szerszy i obejmuje działania ochrony cywilnej, służb ratunkowych, straży przybrzeżnej, ochrony granic, jest także ważnym narzędziem potwierdzania czasowego transakcji finansowych oraz badań naukowych w dziedzinach takich, jak m.in. meteorologia, monitorowanie ruchu Ziemi, ochrona środowiska, rolnictwo i rybołówstwo. Zakres usług oferowanych w projekcie Galileo obejmuje zarówno bezpłatne serwisy otwarte: Open Access Service (OAS), Safety of Life (SoL), i Search and Rescue Service (SaR), jak i płatne i wymagające licencji - Commercial Service (CS), kontrolowane przez administrację państwową - Public Regulated Service (PRS), ale przez to z gwarancją ciągłości i niezawodności systemu (Un système..., 2003). Szacunkowe wyniki badań, przeprowadzonych m.in. na zlecenie Komisji Europejskiej, wskazują, iż przychody, jakich operator systemu Galileo może oczekiwać od firm świadczących usługi LBS, to rząd wielkości $300 \mathrm{mln}$ euro rocznie. 


\section{GALILEO W KONTEKŚCIE INTENSYFIKACJI POWIĄZAŃ MIĘDZYNARODOWYCH}

Odrębność projektu Galileo od innych europejskich programów satelitarnych nie wynika z jego złożoności technologicznej (poza zegarami atomowymi wszystkie niezbędne technologie zostały opracowane przy wcześniejszych projektach kosmicznych), prowadzono również kosztowniejsze inwestycje, przykładowo w ramach europejskiego kosmodromu w Gujanie Francuskiej. Nie miały one jednak tak wyraźnego znaczenia strategicznego. Instytucje kosmiczne nie były formalnie powiązane ze zintegrowanymi strukturami europejskimi, nie przywiązywano także tak istotnej wagi do politycznych aspektów projektów kosmicznych. W ramach projektu Galileo nastąpiło zbliżenie instytucji politycznych (Rada Europy, Parlament Europejski, Komisja Europejska) z europejskimi instytucjami kosmicznymi. Rynek usług radionawigacji satelitarnej znajduje wsparcie w rozlicznych działaniach wspólnoty europejskiej w zakresie prawodawstwa, co ma diametralne znaczenie dla zapewnienia ekonomicznej żywotności nowatorskich technologii. W przypadku projektu Galileo są to przykładowo Dyrektywy Parlamentu Europejskiego i Rady: 2002/59/WE w sprawie wspólnotowego monitorowania i informacji o ruchu statków, 2004/52/WE w sprawie interoperacyjności systemów elektronicznych opłat drogowych w UE, 2005/44/WE w sprawie zharmonizowanych usług informacji rzecznej na śródlądowych drogach wodnych, czy też Zalecenie Komisji z dnia 25 lipca 2003 r. dotyczące świadczenia usług pogotowia telefonicznego z lokalizacją rozmówcy (E112).

Globalna presja przedsiębiorstw i instytucji reprezentujących interesy licznych państw w zakresie szeroko rozumianego zapotrzebowania na cywilny system nawigacyjny, pomimo europejskich założeń projektu Galileo, doprowadziła do współpracy międzynarodowej, czego dowodem są rozliczne umowy w zakresie nawigacji satelitarnej, zawarte przez UE, m.in.:

- umowy z Chinami: z 30 października 2003, dotycząca chińskiego uczestnictwa w programie Galileo, z 9 października 2004 stanowiąca o przyjęciu Chińskiego Narodowego Centrum Teledetekcji w poczet członków Galileo Joint Undertaking (GJU) oraz 3 kontraktów z 28 lipca 2005, potwierdzających zaangażowanie Chin w budowę systemu Galileo,

- umowy z Izraelem: z 13 lipca 2004, w sprawie izraelskiego uczestnictwa w programie Galileo oraz 6 września 2005 w sprawie przyjęcia w poczet członków GJU,

- umowa z Ukrainą z 3 czerwca 2005, dotycząca ukraińskiego uczestnictwa w programie Galileo,

- umowy z Norwegią i Argentyną z 18 lipca 2005, w sprawie uczestnictwa tych państw w programie Galileo,

- umowa z Indiami z 7 września 2005, dotycząca udziału Indii w programie Galileo,

- umowa z Marokiem z 8 listopada 2005, w sprawie uczestnictwa Maroka w programie Galileo,

- umowy z Koreą Płd. z 18 lipca 2005 i z 12 stycznia 2006 dotyczące udziału tego kraju w programie Galileo,

- porozumień o współpracy z Kanadą, Australią, Arabią Saudyjską i Brazylią.

$\mathrm{Na}$ transformację struktury przemysłowego projektu, jakim jest Galileo, zarówno do obecnego stanu prac jak i w zakresie przyszłego funkcjonowania systemu, wpływ miały porozumienia podpisane ze Stanami Zjednoczonymi. Początkowo pełną interoperacyjność systemu europejskiego i amerykańskiego uzyskano po porozumieniu z 26 czerwca 2004, 
a jego kontynuacją były prowadzone wspólnie prace nad zwiększeniem możliwości oferowanych odbiorcom przez systemy GPS i Galileo. Z czasem, gdy połączone kapitały krajów Unii Europejskiej i państw współpracujących nie były w stanie osiagnąć projektowej operacyjności systemu Galileo przed 2010 r. (przyczyny zostaną omówione poniżej), w miejsce niekompatybilnej i konkurencyjnej alternatywy dla GPS pojawił się projekt współpracy UE ze Stanami Zjednoczonymi. Namacalnymi efektami porozumienia z lipca 2007 r. będzie uniezależnienie dostawców sprzętu od jednego operatora, obniżenie całkowitych kosztów ponoszonych przez właścicieli systemów, a „dwusystemowy” układ satelitów umożliwi dokładniejszą lokalizację obiektów wskazanych przez użytkownika korzystającego z pełni kompatybilnego odbiornika GPS/Galileo. Niewłaściwa będzie więc nazwa „odbiornik GPS”, która na dobre przylgnęła do tego typu urządzeń.

Przedsięwzięcie o nazwie Galileo mocno osadzone jest w ramach Strategii Lizbońskiej na rzecz wzrostu i zatrudnienia oraz w specyfice projektów know-how. Tylko w krajach UE w sferze programów GNSS planuje się stworzyć 150 tys. miejsc pracy, w tym głównie w sektorach nowoczesnych. Nad projektem Galileo pracują międzynarodowe zespoły naukowców i przedstawicieli różnych branż przemysłu, a badania naukowe oprócz kwestii technicznych obejmują obszar zagadnień związanych z wdrożeniem systemu do życia codziennego odbiorców. W znacznej mierze dotyczą adaptacji systemu do prac prowadzonych w ramach współpracy międzynarodowej.

To, jaki wpływ mogą mieć procesy integracji europejskiej na przebieg projektów przemysłowych, uwidoczniło się także wyraźnie w przypadku omówionych poniżej problemów finansowania projektu Galileo. Odrzucenie koncepcji kontynuacji partycypacji kosztów przez Europejską Agencję Kosmiczną wynikło z problematycznej sytuacji, w której nie wszystkie kraje UE należą do ESA i odwrotnie. Polska jest przykładem kraju, który nie jest członkiem ESA i stara się o uzyskanie statutu państwa współpracującego, w ten sposób będzie miała możliwość uczestnictwa we wspólnych projektach ESA i UE oraz ubiegania się o kontrakty publiczne na europejskim rynku kosmicznym. Należy wyraźnie zaznaczyć, że Polska wpłacając składkę do budżetu UE, pośrednio finansuje projekt Galileo, natomiast jej udział w ramach 6. Programu Ramowego wynosi zaledwie 600 tys. euro oraz w postaci kontraktów poza 6. PR tylko 140 tys. euro, czyli znacznie poniżej poziomu wpłat. W sytuacji, w której ośrodki francuskie czy też niemieckie realizują kontrakty rzędu miliardów euro, Polska „finansuje laboratoria i przemysł zachodnioeuropejski” (Knapińska 2007). Polska w ramach programu Galileo realizuje projekt PACIFIC, pilotowany przez Przemysłowy Instytut Automatyki i Pomiarów w Warszawie, mający na celu zapoznanie potencjalnych użytkowników z usługą PRS, oraz projekt FieldFact dotyczy prezentacji i promocji GNSS w rolnictwie, prowadzony przez Uniwersytet Warmińsko-Mazurski w Olsztynie. Elementem segmentu naziemnego EGNOS jest, zlokalizowana w Centrum Badań Kosmicznych PAN w Warszawie, jedna z 34 stacji referencyjne RIMS.

\section{Partnerstwo PUBliCZnO-PRYWATnE. MODYFiKACJA PROJEKTU}

Według wytycznych UE projekt Galileo miał stanowić przedmiot partnerstwa publiczno-prywatnego. Sektor publiczny (UE i ESA) ponosi odpowiedzialność, także finansowa, za początkowe fazy projektowe, czyli definicję systemu oraz rozwój i walidację na orbi- 
cie pierwszych czterech satelitów. Sektor prywatny miał być odpowiedzialny za wdrożenie i funkcjonowanie systemu, czyli m.in. uzupełnienie liczby satelitów, rozwój infrastruktury naziemnej i dostarczenie usług użytkownikom. W fazie wdrażania 1/3 nakładów dotyczyłoby sektora publicznego, a 2/3 partnera prywatnego. Późniejsze dochody rynkowe powinny sfinansować koszty funkcjonowania systemu, w ten sposób nakłady sektora publicznego uległyby redukcji do zera (Kobierzycka 2006). W fazie wdrażania jednostki prywatne w ramach koncesji powinny otrzymać wyłączne prawo do korzystania z segmentów systemu przez 20 lat w zamian za wspomniane pokrycie przez każdą z nich co najmniej 2/3 kosztów budowy infrastruktury. Koncesji udziela organ nadzoru GNSS, a infrastruktura, zgodnie z założeniami projektu, pozostaje własnością publiczną.

Przedsiębiorstwo Galileo, które powstało na mocy rozporządzenia Rady z dnia 21 maja 2002, a po 1 stycznia 2007 organ nadzoru GNSS, prowadziły negocjacje z blokiem partnerów prywatnych, który to sektor stanowiły: Aena, Alcatel, EAD-S, Finmeccanica, Hispasat, Inmarsat, Thales i TeleOp. W prywatnym sektorze w ramach partnerstwa publiczno-prywatnego nie wystąpiły firmy polskie, pomimo znaczących atrybutów w postaci naukowców, inżynierów i menedżerów, instytutów naukowych, przemysłu oczekującego na kontrakty, niskich kosztów produkcji i tradycji, przykładowo przemysłu lotniczego. Wspólna oferta konsorcjów, w porównaniu $\mathrm{z}$ wariantem pojedynczych wyżej wymienionych podmiotów, wykazała znaczną redukcję nakładów finansowych i wzrost dochodów z usług komercyjnych. Zgodnie z zasadami partnerstwa publiczno-prywatnego negocjacje prowadzono w celu oceny, która ze stron (sektor prywatny, sektor publiczny) jest w stanie lepiej zminimalizować każde z dziewięciu rodzajów ryzyka projektu Galileo: przekroczenia kosztów, realizacji, wyników, koncepcji, dochodu i rynku, rozmieszczenia, pokrycia ryzyka projektu, rekompensaty w przypadku wypowiedzenia i refundacji. Rozbieżności w założeniach partnerstwa publiczno-prywatnego wystąpiły głównie w kwestii podziału rynku związanego z koncepcją systemu i ryzyka związanego z dochodem handlowym (Taking stock... 2006).

W przeciwieństwie do założeń samofinansującego się Galileo, System GPS utrzymywany jest w całości przez Stany Zjednoczone, które inwestują rocznie $750 \mathrm{mln}$ USD, a udostępniony został, z pewnymi ograniczeniami, bezpłatnie na całym świecie. Zakładane potencjalne zyski z pracy systemu Galileo zależne będą od zespołu czynników, które stanowią jednocześnie argument krytyków przebiegu projektu, zarzucających niedoszacowanie dochodów z przyszłej pracy systemu. W warunkach konkurencji ze strony GPS i GLONASS zbyt mało uwagi poświęcono bowiem:

- modernizacji GPS i GLONASS, zmierzającej do oferowania parametrów usług przekraczających lub przynajmniej równych z istniejącymi systemami GNSS (uruchomienie GPS III w podobnych perspektywach czasowych jak GALILEO),

- utrudnień w konkurencji płatnych chipów GALILEO z bezpłatnymi GPS,

- integracji różnych systemów GNSS, której efekty, w przeciwieństwie do Commercial Service Galileo, zapewnią bezpłatnie wiarygodność, ciagłość i dostępność usług na poziomie wystarczającym do zaspokojenia potrzeb wielu komercyjnych aplikacji.

Kolejną komplikacją podwyższającą ryzyko sektora prywatnego jest fakt, że partner prywatny nie może efektywnie zarządzać ryzykiem popytu, ponieważ częściowo zależy ono od decyzji władz publicznych. Wyraźne są także różnice w sposobie myślenia i działania pomiędzy przedstawicielami biznesu i biurokracji europejskiej (Kobierzycka 2006). Znaczne jest również ryzyko projektowe, wynikające z sytuacji, w której prywatny koncesjonariusz przejmuje system zaprojektowany i przetestowany przez stronę publiczną (ESA). 
Parlament Europejski, w świetle obaw nad postępami prac nad projektem, w rezolucji z 24 kwietnia 2007 ponowił swoje zapewnienia o wsparciu programu Galileo, ale wyraźnie wezwał do wzmocnienia zarządzania publicznego (Communication... 2007). Opóźnienie w przebiegu projektu uznano za wynik nierozwiązanych różnic zdań co do podziału prac przemysłowych, błędnej oceny, według której ryzyko rynkowe mogłoby być przeniesione na sektor prywatny, nierozwiązanych negocjacji dotyczących przeniesienia ryzyka projektowego, złożoności technicznej programu oraz niewystarczająco silnego i klarownego zarządzania. Przyjmując projekt budżetu ogólnego UE na rok 2008, ograniczono środki przewidziane na wspólną politykę zagraniczną i bezpieczeństwo, ale zwiększono w pełni już publiczne finansowanie faz projektu Galileo, z planowanego 1mld euro do 3,4 mld euro (Regulation ... 2007).

Należy wyraźnie nadmienić, iż groźba zatrzymania lub obniżanie kosztów projektu wiązałaby się z całym szeregiem negatywnych konsekwencji, wynikających z podniesienia zależności nawigacji europejskiej od systemu GPS oraz potencjalnie od innych rozwijających się systemów GNSS. Gospodarka europejska byłaby jedyną nieposiadającą atutu systemu cywilno-militarnego lub militarnego. Wiązałoby się to także z utratą znacznych makro-ekonomicznych możliwości dla europejskiego sektora przemysłowego i usług oraz odpływem fachowców w dziedzinie GNSS. Wszelkie radykalne zmiany projektu Galileo to unieważnienie istniejących kontraktów przemysłowych w fazie rozwoju, z pełnym powtórzeniem procesów przetargowych, prowadzące do efektu utraty dotychczasowych inwestycji, opóźnionego wejścia na rynek systemu o obniżonych parametrach i niską odpornością na konkurencję. Potencjalne oszczędności kosztów przy koncepcji okrojonego systemu mogłyby prowadzić do efektu odwrotnego od zamierzonego, a należy zaznaczyć, że UE zaangażowała już pokaźne fundusze w rozwój programów GNSS.

\section{WNIOSKI}

Wizja cywilnej europejskiej nawigacji satelitarnej, realizowana od lat 90. XX w., o założeniach uniezależniających kraje UE od amerykańskiego systemu GPS, w warunkach silnych procesów integracji europejskiej i wyraźnego zainteresowania ze strony krajów pozaeuropejskich, już w fazie projektowej podlega licznym transformacjom. Ten europejski „globalny” system ma istotne znaczenie dla rozwoju bezpieczeństwa i gospodarki krajów UE, jest filarem europejskiej polityki kosmicznej, symbolem ambicji Europy w zakresie technologii innowacyjnych, ale w fazie realizacji będzie odgrywał istotną rolę w rozwoju społeczeństw informacyjnych nie tylko tej części świata. Projekty typu Galileo rozpatrywane są w wymiarze globalnym, przekaz informacji w ramach funkcjonowania systemów GNSS ma bowiem charakter ponadgraniczny i natychmiastowy, a czynniki geograficzne nie stanowią bariery w przepływie produktów i technologii. Intensyfikacja powiązań międzynarodowych, zarówno w zakresie państw europejskich, jak i poza kontynentem, jest próbą ucieczki państw nie biorących udziału w projektach GNSS od marginalizacji w zakresie nowoczesnych technologii informacyjnych. Z początkiem XXI w. nastapił bowiem intensywny rozwój branży nawigacji satelitarnej, a wartość aplikacji i urządzeń w segmencie GNSS rośnie najszybciej wśród rynków wysokiej technologii. 
Transformacja programu Galileo, największego projektu przemysłowego realizowanego w ramach zintegrowanych struktur europejskich, początkowo planowanego do uruchomienia w 2008 r., przebiega w warunkach rosnącego ryzyka potencjalnych zysków z pracy systemu. Fiasko założeń partnerstwa publiczno-prywatnego wynikło głównie rozbieżności w kwestii ryzyka związanego z dochodem handlowym i z rozwojem rynków. W 2013 r., czyli w momencie pełnej operacyjności Galileo, będą funkcjonować już pierwsze satelity GPS III, a wysoka dokładność tego amerykańskiego systemu, podobnie jak innych zintegrowanych systemów GNSS, będzie stanowić konkurencję dla amatorskich i komercyjnych aplikacji. Coraz szersza współpraca UE ze Stanami Zjednoczonymi w zakresie GNSS jest jednak wyraźnym sygnałem odejścia od mechanizmów konkurencji systemów Galileo i GPS i powolnego zwrotu w stronę koncepcji wielosystemowego układu satelitów, kompatybilności odbiorników Galileo/GPS, a przez to m.in. obniżenia całkowitych kosztów ponoszonych przez właścicieli systemów.

Konieczność kontynuacji projektu Galileo, ze względu na jego wartość strategiczna, wymiar gospodarczy i technologiczny oraz znaczenie w kontekście Strategii Lizbońskiej, była wielokrotnie podkreślana przez Radę Europejską w czasie szczytów w Kolonii, Feira, Nicei, Sztokholmie, Laeken, Barcelonie i Brukseli. Ważnym aspektem, w świetle pięcioletnich opóźnień projektu Galileo, jest konieczność uświadomienia społeczeństwa europejskiego o konsekwencjach spowolnienia i ewentualnego zatrzymania programu GNSS. W takiej sytuacji Europa skazałaby się w dłuższym okresie na korzystanie z zagranicznych sygnałów satelitarnych, w przypadku których ma bardzo ograniczoną kontrolę nad jakością, dostępnością i ceną, bądź nie ma takiej kontroli w ogóle, ale także odpływ fachowców w dziedzinie GNSS z Europy oraz utratę znacznych możliwości makroekonomicznych przez europejskie przedsiębiorstwa przemysłowe i usługowe. Wyniki badań rynku z 2007 r. (Galileo... 2007) wskazują, iż spośród 25 tys. ankietowanych mieszkańców UE aż 80\% popiera ideę niezależnego systemu nawigacji satelitarnej, a 63\% ludności (66\% Polaków) wyraziłoby zgodę na dodatkowe finansowanie w celu ukończenia tego przedsięwzięcia, pomimo iż w pytaniu ankietowym pojawiła się informacja o wydatku 2,4 mld euro, równowartości budowy $400 \mathrm{~km}$ autostrady. Ten wysoki poziom świadomości niweluje jednak fakt, iż tylko 44\% respondentów uważa, że efekty zaniechania programu Galileo dla wizerunku UE byłyby fatalne, a $41 \%$ twierdzi, że nie miałoby to żadnych negatywnych skutków.

\section{Literatura}

Business in satellite navigation, 2005, Official brochure Directorate - General Energy and Transport, second edition, Brussels, ss. 36

Galileo at a cross-road: The implementation of the european GNSS programmes, 2007, Communication from the Commission to the European Parliament and the Council (COM 2007, 261), Brussels, ss. 18

General public survey on the European Galileo Programme, 2007, Citizen Survey, Flash EB Series, no 211 , ss. 48

Knapińska A., 2007, Kosmos naszq specjalnościq?, „Materiały Ministerstwa Nauki i Szkolnictwa Wyższego", nr 4 (125)

Kobierzycka A., 2006, Matżeństwo z rozsqdku, „Nawi”, nr 3 (13), s. 3-5

Kramarz P., Warcholik W., 2005, Od GPS do Galileo, „Konspekt”, nr 2 (23), s. 37-41 
Progressing Galileo: Re-profiling the european GNSS programmes, 2007, Communication from the Commission to the European Parliament and the Council, (COM 2007, 534), Brussels, ss. 16

Regulation of the Commission to the European Parliament and the Council on the further implementation of the European satellite radionavigation programmes, 2007 (COM 2007, 535), Brussels, ss. 32

Taking stock of the Galileo programme, 2006, Communication from the Commission to the European Parliament and the Council (COM 2007, 272), Brussels, ss. 10

The current and future world-wide market for GNSS land and marine applications, 2006, Location - The portal on Positioning \& Navigation, September - October, s. 1-3, (www.location.net.in)

Un système de positionnement; un enjeu stratégique scientifique technique, 2003, Académie de marine, Bureau des longitudes, Académie nationale de l'air et de l'espace, Paris, ss. 203

\section{European GNSS programmes on the market of global navigation systems}

The study includes the description of development conditions for the satellite navigation programme Galileo. Its also includes some aspects of the Galileo programme accomplishment, especially its influence on the integration process in Europe and tightening the international connections. The programme has been implemented since the 1990s and its aim is to ensure the independence of the EU countries in such sectors of their economy which are based on the precise information related to location and time. Galileo has also its overregional dimension, which is the result of satellite constellation and its global reach. It is the biggest industrial project conducted within the integrated European structures. What is more, the distinction of Galileo among other European satellite programmes has its roots in its crucial strategic significance rather than in technology or investment costs. So far, the cosmologic institutions have not been formally connected with the integrated European structures, and less importance has been attached to political aspects of their projects. The transformation of the Galileo programme is proceeding in the condition of potential incomes risk from the system work. The fiasco of public and private partnership establishments was the result of differences in estimating the risk of trade incomes and market development. In 2013 Galileo will be in its full operation process and first GPS III satellites will work, what is more, the high precision of this American system and other integrated GNSS systems will establish competition in terms of commercial and amateur aplications. Widening the cooperation between the EU countries and the USA implies many positive effects, such as creating the idea of a multi-system satellite scheme, the compatibility of Galileo and GPS receivers and, what follows, the increase of navigation precision and reduction of overall costs borne by the system owners. 